\title{
VALUCH TIBOR: MAGYARORSZÁG TÁRSADALOMTÖRTÉNETE A XX. SZÁZAD MÁSODIK FELÉBEN
}

\author{
(Osiris Kiadó, Budapest, 2001. 389 o.)
}

\section{CSIZMADIA ZOLTÁN}

A társadalomtudomány, és kimondottan a társadalomtörténet iránt érdeklődők remélhetőleg - széles közönsége újabb értékes mủvel gazdagodhatott. Valuch Tibor könyve az első kísérlet arra, hogy az elmúlt évszázad második felében lezajló hazai társadalmi folyamatokat (beleértve a rendszerváltás utáni társadalmi változásokat is) úgy összegezze, hogy egyaránt figyelembe veszi a mikro- és a makrostrukturális változásokat. A második világháborút követő évtizedek magyar társadalomtörténete még a rendszerváltás után több mint egy évtizeddel sem tartozik a legtöbbet elemzett, a legalaposabban feldolgozott kutatási területek közé. A téma oktatásával kapcsolatban még kedvezőtlenebb a kép. Persze mentegetőzhetünk azzal, hogy hiányzik a történelmi távlat, sokak számára az utóbbi 40-50 év a közelmúltat, a személyesen megélt, való életet jelenti, amely alapjaiban nehezíti a téma objektív, tudományos, és nem utolsó sorban politikamentes kezelését és feldolgozását. Ez akkor válik fontos kérdéssé, ha a társadalomtörténettel foglalkozó szakemberek a puszta leíráson túl magyarázatokat is keresnek. Persze azt sem szabad figyelmen kívül hagyni a szerző megítélése szerint, hogy a tág értelemben vett magyar társadalomtudományosság a rendszerváltást követő egy évtized során nem sietett szembe nézni a „szocialista kor" történéseivel.

A könyv önmagába süríti a szakmai igényességet és az oktatási tapasztalatok eredményeit. Ebben az értelemben nemcsak az első szakmai alapossággal elkészített összefoglalása a korszak társadalomtörténeti jellemzőinek, hanem az első tankönyvként használható munka is. Ez érvényes a szerkezeti jellemzőkre (logikailag egymásra épülő fejezetek), a felvonultatott bibliográfiai apparátusra (a szakirodalom témák szerinti tagolása), a fogalmazás félreérthetetlenségére, a gazdag táblázatés ábrajegyzékre ( 37 táblázat, 22 ábra, több mint 60 kép).

A könyv szerkezetét tekintve 14 fejezetre tagolódik, amelyek három nagyobb blokkba sorolhatók be. Az első négy fejezet a „társadalmi viszonyok külső jellemzőitől indul el", és bevezeti az olvasót a korszakolással és a különbözö társadalomátalakítási, társadalomértelmezési kísérletekkel kapcsolatos témákba. Makroszinten sor kerül a demográfiai viszonyok bemutatására, a társadalom térbeli változásainak ismertetésére és a magyarországi kisebbségek, illetve a kisebbségben élő magyarok sorsának felelevenítésére.

A második szerkezeti blokk a társadalmi struktúra és a mobilitás tárgykörét fedi le, számbaveszi a társadalomszerkezeti jellegzetességeket, és leírja a makrotársadalmi rétegek helyzetét a második világháborútól kezdődỏen a kilencvenes 
évek végéig. Olyan kérdésekre ad választ, hogy milyen változások történtek társadalmunk szerkezeti alapvonásaiban, milyen fogalmi kerettel, milyen struktúraképekkel értelmezhetỏ a magyar társadalom szerkezete (pl. munkajelleg-csoportok, L-modell, két háromszögmodell), léteznek-e a kontinuitásra utaló jelenségek a szerkezeti változásokban, és hol figyelhetőek meg a töréspontok? Külön fejezeteket szentel az egyes foglakozási csoportoknak/rétegeknek (elitek, vezető csoportok; értelmiségiek, közalkalmazottak, tisztviselök, szellemi foglalkozásúak; önállók, maszekok; a falusi társadalom szereplöi; a városi munkásság).

A harmadik, záró blokk négy fejezete ismét távolabbi perspektívából követi figyelemmel (1) a hatalom és társadalom viszonyát (politikai részvétel és tagoltság), (2) a közgondolkodás, az értékrendszerek és társadalmi kapcsolatok alakulását, (3) a hétköznapi élet formáit és lehetöségeit (életmód, lakásviszonyok, öltözkődés, táplálkozás, szokásrendszer és szabadidő), (4) és a ṡzociális viszonyok változásait. A könyvben rejló legnagyobb érték talán abban rejlik, hogy a makroszintü politikai, gazdasági és társadalmi viszonyokon túl (amelyeket számos tanulmány és cikk taglal) megismerhetjük az utóbbi évtizedekben uralkodó közvélekedéseket, az eltérő értékrendszereket és ideológiákat. Bepillanthatunk a hétköznapok realitásába (pl. falusi konyhabelső, a háztartások felszereltségének változása), szemünk elé tárul a gázgyári telep kétszobás munkáslakásának az alaprajza. A leírtaknál árulkodóbb lehet például „a fürdőszoba Horváth Pál müvezető otthonában, az újonnan épült Béke úti lakótelepen. 1955" címü fénykép. Megtudhatjuk, hogy miként alakult az egy före jutó élelmiszerfogyasztás 1950-1996 között, sőt még arról is lehet némi elképzelésủnk a könyv fellapozása után, hogy milyen volt 'egy földművesszövetkezet cukrászdája 1954-ben.

A könyvben szereplö fejezetenkénti szakirodalom-jegyzék megfelelően kiegészíti az egyes részek tartalmi mondanivalóját, és megkönnyíti a megállapítások továbbgondolását. Nagy segítséget jelenthet a diákoknak, vagy azoknak a szakembereknek és a terület iránt érdeklődő olvasóknak, akik az egyes témákban alaposabb ismeretekre vágynak, hiszen tematikusan megismerhetjük a leglényegesebb kiindulóirodalmakat, és a szerző által kiemelt specifikus témájú tanulmányokat, könyveket. Hasznosak lehetnek a szakirodalmi jegyzékek abban az esetben is, ha a különböző témakörök rendszerváltás utáni helyzetképének tanulmányozásához kezdünk hozzá.

Összefoglalva, megállapíthatjuk, hogy Valuch Tibor az MTA tudományos fömunkatársa, az ELTE docense széles körü tudományos háttérre támaszkodva (szociológia, történelem, társadalom-néprajz, statisztika), saját kutatási és oktatási tapasztalatait felhasználva a korszak társadalomtörténeti jellemzőinek és folyamatainak „tényszerü és tárgyilagos összefoglalására” törekedett. Kivételesen egyetérthetünk a hátsó borító marketing-szövegével: mely szerint ,az adatgazdag kötet használatát táblázatok, grafikonok, valamint az egyes témakörökben történő tájékozódást segítő irodalomjegyzék könnyíti meg az olvasó számára. A gondosan válogatott fotók széleskörúen illusztrálják e korszak társadalmi változásait. A kötet egyetemi és fỏiskolai tankönyvként, valamint tudományos kézikönyvként egyaránt jól használható, s emellett nagy haszonnal forgathatják mindazok, akik érdeklödnek a közelmúlt magyar történelme iránt". 